\title{
PERAN MOTIVASI BELAJAR PADA HUBUNGAN ANTARA FAKTOR EKSTERNAL TERHADAP HASIL BELAJAR
}

\author{
Tyas Azmi Deviyanti* ${ }^{*}$, Haryadi ${ }^{1}$, Ary Yunanto ${ }^{1}$ \\ 1)Program Pascasarjana Magister Manajemen, Universitas Jenderal Soedirman, Indonesia \\ *Email corresponding author: tyasazmideviyanti@gmail.com
}

\begin{abstract}
Abstrak
Penelitian kuantitatif ini bertujuan untuk menganalisis pengaruh faktor eksternal yaitu fasilitas belajar, kompetensi guru dan media pembelajaran terhadap motivasi belajar peserta didik, serta menganalisis pengaruh ketiga faktor eksternal tersebut terhadap hasil belajar peserta didik baik secara langsung maupun secara tidak langsung dengan faktor mediasi berupa motivasi belajar. Penelitian ini dilakukan pada peserta didik Kompetensi Keahlian Bisnis Daring dan Pemasaran SMK se-Kecamatan Bumiayu dengan jumlah responden sebanyak 120 peserta didik. Teknik pengumpulan data pada penelitian ini menggunakan kuesioner. Hasil penelitian dan analisis data dengan analisis jalur melalui model regresi linear menunjukkan bahwa terdapat pengaruh positif antara semua faktor eksternal terhadap motivasi belajar; terdapat pengaruh positif antara fasilitas belajar dan media pembelajaran terhadap hasil belajar; namun, tidak terdapat pengaruh antara kompetensi guru terhadap hasil belajar; terdapat pengaruh positif antara motivasi belajar terhadap hasil belajar; dan motivasi belajar secara signifikan berpengaruh positif dalam memediasi hubungan ketiga faktor eksternal terhadap hasil belajar.
\end{abstract}

Kata Kunci: Faktor Eksternal, Fasilitas Belajar, Kompetensi Guru, Media Pembelajaran, Motivasi Belajar, Hasil Belajar.

\begin{abstract}
This quantitative research aimed to analyze the influence of external factors such as learning facilities, teachers' competency, and learning media towards learning motivation of students, and also to analyze those three external factors toward learning result of students both directly and indirectly through motivation as the mediation factor. This research was conducted to students of all Vocational High Schoolin Bumiayu majored in competency of online business skill and marketing. There are 120 respondents in this study. Data collecting technic in this research is using questionnaire. The result of research and data analysis using path analysis through model of linear regretion shows that there are positive influences of all external factors toward learning motivation; there are positive influences of learning facilities and learning media towards learning result; teachers' competency has no positive effect towards learning result; there are positive influences of learning motivation towards learning result; and learning motivation is significantly giving positive influences in mediating the relationship between three external factors towards learning result.
\end{abstract}

Keywords: External Factors, Learning Facility, Teachers' Competency, Learning Media, Learning Result.

\section{PENDAHULUAN}

Pendidikan akan selalu berkaitan dengan kegiatan belajar mengajar. Dari kegiatan belajar mengajar tersebut diperoleh hasil belajar peserta didik. Hasil belajar yaitu kecapakan yang diperoleh peserta belajar ketika dia telah menjalani suatu peristiwa dalam kegiatan belajar (Sudjana, 2009). Hasil belajar terbagi dalam berbagai kemampuan yaitu dalam bidang pengetahuan, keterampilan, dan sikap. Kemampuan pengetahuan terdiri dari kecapakan untuk berpikir. Kemampuan sikap merupakan sesuatu yang berhubungan dengan perilaku peserta didik. Sementara kemampuan keterampilan berhubungan dengan pergerakan peserta didik untuk mempraktikkan sesuatu yang ia pelajari setelah menerima pembelajaran. 
Kegiatan belajar mengajar tidak selamanya berjalan lancar dan memperoleh hasil yang diharapkan. Pada proses pembelajaran masih terdapat peserta didik yang belum maksimal sehingga berdampak pada hasil belajar mereka. Pernyataan ini dapat terlihat dari terdapatnya peserta didik yang masih belum memperoleh Kriteria Ketuntasan Minimal (KKM). Berdasarkan data dari Penilaian Tengah Semester (PTS) Kompetensi Keahlian Bisnis Daring dan Pemasaran, masih terdapat peserta didik yang belum mencapai KKM dalam setiap mata pelajaran. Berikut Tabel 1.1 yang menyajikan data nilai murni peserta didik sebelum mendapatkan remidial.

Tabel 1

Rekapitulasi Ketuntasan Penilaian Tengah Semester

Kompetensi Keahlian Bisnis Daring dan Pemasaran

\begin{tabular}{clrrrr}
\hline \multirow{2}{*}{ Kelas } & \multicolumn{2}{c}{ Kelompok Mapel } & \multicolumn{2}{c}{ Tahun 2017/2018 } & \multicolumn{2}{c}{ Tahun 2018/2019 } \\
\cline { 3 - 6 } & & Tuntas & $\begin{array}{c}\text { Tidak } \\
\text { Tuntas }\end{array}$ & Tuntas & $\begin{array}{c}\text { Tidak } \\
\text { Tuntas }\end{array}$ \\
\hline \multirow{2}{*}{ X } & Muatan Nasional & $59,52 \%$ & $40,48 \%$ & $51,30 \%$ & $48,70 \%$ \\
& Muaytan Kewilayahan & $57,94 \%$ & $42,06 \%$ & $69,20 \%$ & $30,80 \%$ \\
& Muatan Kejuruan & $39,29 \%$ & $60,71 \%$ & $55,80 \%$ & $44,20 \%$ \\
\hline XI & Muatan Nasional & $36,29 \%$ & $63,71 \%$ & $41,00 \%$ & $59,00 \%$ \\
& Muatan Kewilayahan & $71,11 \%$ & $28,89 \%$ & $60,00 \%$ & $40,00 \%$ \\
& Muatan Kejuruan & $31,85 \%$ & $68,15 \%$ & $65,00 \%$ & $35,00 \%$ \\
\hline \multirow{2}{*}{ XII } & Muatan Nasional & $35,78 \%$ & $64,22 \%$ & $24,82 \%$ & $75,18 \%$ \\
& Muatan Kewilayahan & $76,47 \%$ & $23,53 \%$ & $22,96 \%$ & $77,04 \%$ \\
& Muatan Kejuruan & $60,29 \%$ & $39,71 \%$ & $51,11 \%$ & $48,89 \%$ \\
\hline
\end{tabular}

Sumber: Guru mata pelajaran Bisnis Daring dan Pemasaran

Pada struktur kurikulum kompetensi keahlian Bisnis Daring dan Pemasaran terdapat tiga kelompok mata pelajaran yaitu kelompok mata pelajaran muatan nasional, kewilayahan, dan peminatan kejuruan. Dari data diatas menunjukkan bahwa pada tahun pelajaran 2017/2018 dan 2018/2019 ketidaktuntasan hasil belajar peserta didik bersifat fluktuasi artinya mengalami kenaikan dan penurunan baik pada setiap kelompok mata pelajaran maupun setiap kelas. Pada kelompok mata pelajaran muatan nasional kelas X ketidaktuntasan hasil belajar peserta didik mengalami kenaikan dari 40,48 \% menjadi 48,70 \%. Pada kelas XI untuk mata pelajaran muatan nasional, ketidaktuntasan hasil belajar peserta didik mengalami penurunan dari $63,71 \%$ menjadi 59,00 \%. Sedangkan pada kelas XII dengan kelompok mata pelajaran yang sama mengalami kenaikan ketidaktuntasan hasil belajar dari 64,22 \% menjadi 75,18 \%. Pada kelompok mata pelajaran muatan kewilayahan di kelas $\mathrm{X}$ mengalami penurunan ketidaktuntasan hasil belajar peserta didik dari 42,06 \% menjadi 30,80\%. Berbeda dengan kelas XI yang mengalami kenaikan ketidaktuntasan hasil belajar dari 28,89 \% menjadi 40,00\%. Sedangkan pada kelompok mata pelajaran muatan peminatan kejuruan kelas X mengalami penurunan ketidaktuntasan hasil belajar peserta didik dari 60,71 \% menjadi 44,20\%. Pada kelas XI untuk mata pelajaran muatan peminatan kejuruan, ketidaktuntasan hasil belajar peserta didik mengalami penurunan 68,15 \% menjadi 35,00 \%. Pada kelas XII dengan kelompok mata pelajaran peminatan kejuruan mengalami kenaikan ketidaktuntasan hasil belajar peserta didik dari 39,71 \% menjadi 48,89 \%. Dengan demikian, data yang telah dipaparkan diatas menyatakan bahwa hasil belajar peserta didik pada Kompetensi Keahlian Bisnis Daring dan Pemasaran masih dikategorikan rendah.

Motivasi, perilaku peserta didik terhadap belajar, konsentrasi, kebiasaan belajar, faktor guru, pengolahan bahan materi, faktor lingkungan sosial, serta sarana prasarana belajar 
merupakan masalah belajar yang memengaruhi pencapaian belajar peserta didik (Aunurrahman, 2014). Ketidakberhasilan peserta didik dalam belajar dipengaruhi oleh banyak faktor. Menurut Sudjana (1996) hasil belajar dipengaruhi oleh faktor intern seperti faktor fisik, motivasi, minat, psikologis, kematangan, bakat, dan faktor ekstern yang berkaitan dengan lingkungan keluarga, sekolah dan masyarakat.

Kompetensi guru, media pembelajaran dan fasilitas belajar merupakan faktor eksternal yang memengaruhi hasil belajar peserta didik. Kompetensi guru yaitu penggabungan kemampuan kognitif, psikomotorik, dan afektif seorang guru perlu memilikinya dalam menjalankan tugas. Usman (2011) mengemukakan bahwa guru yang memiliki kompetensi dapat membuat lingkungan sekitar proses belajar mengajar lebih efektif dan dapat mengendalikan kelas sehingga peserta didik mempunyai hasil belajar yang maksimal.

Selain kompetensi guru, media pembelajaran yang digunakan oleh guru dalam menyampaikan pesan kepada peserta didik juga akan berpengaruh terhadap pemahaman pengetahuan yang diterima. Penggunaan media yang sesuai dengan materi pelajaran memberikan dampak baik berupa meningkatnya hasil belajar dan aktivitas siswa dalam belajar karena media dapat membantu peserta didik untuk mengambil, mengolah, serta merangkai ulang gambar dan penjelasan dari ilmu yang sudah dimiliki. Peran media dalam mencapai hasil belajar seperti scaffolding yang membantu aktivitas guru dan siswa di kelas untuk belajar (Satrianawati, 2017).

Fasilitas belajar yang dimiliki sekolah pun akan memengaruhi hasil belajar peserta didik. Fasilitas belajar adalah peralatan dan perlengkapan baik bergerak dan tidak bergerak yang digunakan secara langsung dalam kegiatan pembelajaran supaya tujuan pendidikan berjalan efektif dan efisien. Penelitian yang dilakukan oleh Amah (2015) menunjukkan bahwa lingkungan sosial maupun fasilitas yang ada di sekolah mempunyai pengaruh yang signifikan terhadap hasil belajar peserta didik. Diperkuat dengan penelitian dari Kurniawan (2012) bahwa fasilitas belajar terdapat pengaruh positif terhadap hasil belajar peserta didik. Namun hasil tersebut berbeda dengan penelitian yang dilakukan oleh Wicaksono (2011) bahwa tidak terdapat pengaruh positif dan signifikan antara fasilitas belajar terhadap hasil belajar.

Hasil belajar juga dapat dipengaruhi oleh motivasi belajar peserta didik. Menurut Rifa'i dan Anni (2012), motivasi tidak saja menjadi faktor yang menyebabkan munculnya kegiatan belajar, akan tetapi dapat menjadi faktor yang membuat kegiatan belajar menjadi lancar dan hasil belajar meningkat. Hal ini didukung dari penelitian Nurmala (2014) yang menunjukkan bahwa motivasi belajar mempunyai pengaruh positif terhadap hasil belajar. Artinya motivasi belajar peserta didik yang tinggi dapat meningkatkan hasil belajar. Penelitian dari Novalinda (2017) juga menunjukkan pengaruh yang signifikan pada motivasi belajar terhadap hasil belajar. Oleh karena itu, motivasi belajar akan dijadikan sebagai variabel mediasi karena dapat memengaruhi permasalahan yang telah diidentifikasikan diatas. Berdasarkan fenomena tersebut, peneliti tertarik untuk menganalisis peran motivasi belajar pada hubungan antara faktor eksternal terhadap hasil belajar peserta didik Kompetensi Keahlian Bisnis Daring dan Pemasaran.

\section{TINJAUAN PUSTAKA DAN PENGEMBANGAN MODEL}

\section{Hasil Belajar}

Menurut Djamarah (2002) hasil belajar pada dasarnya yaitu "perubahan" yang ada pada pribadi individu sesudah selesainya mengerjakan kegiatan belajar. Sedangkan pendapat Sudjana (2013) tentang hasil belajar yaitu suatu dampak dari kegiatan study yang diukur dengan memakai instrumen pengukuran contohnya melakukan tes secara tertulis, secara lisan, dan 
dengan kegiatan praktik yang telah dirancang secara matang. Berdasarkan uraian tersebut kesimpulan dari definisi hasil belajar adalah kecakapan yang diterima peserta belajar sesudah menjalankan proses belajar dan diukur dengan alat pengukuran baik tes tertulis, lisan maupun perbuatan pada waktu tertentu. Sudjana (1996) mengemukakan terdapat dua faktor yang memengaruhi hasil belajar antara lain: (1) Faktor intern; merupakan faktor yang muncul dari dalam diri seseorang. Faktor intern berkaitan dengan fisiologis, psikologis, minat, bakat, motivasi, kematangan, dan lain-lain. (2) Faktor ekstern; merupakan faktor yang muncul dari luar diri seseorang meliputi lingkungan keluarga, sekolah dan masyarakat.

\section{Motivasi Belajar}

Winkel (2000) menyebutkan bahwa motivasi belajar yaitu semua daya penggerak psikis dari diri peserta didik yang menampilkan aktivitas belajar untuk menggapai target tertentu. Sedangkan menurut Sardiman (2014) motivasi belajar adalah semua daya penggerak dari diri peserta didik dimana menimbulkan aktivitas belajar yang menjamin kelangsungan dan memberikan arah pada aktivitas belajar sehingga terwujudnya target yang diinginkan oleh subjek belajar. Kesimpulan yang dapat diambil dari beberapa definisi tersebut bahwa mengenai motivasi belajar yaitu tenaga pendorong didalam diri peserta didik untuk menuju suatu tingkah laku tertentu. Yusuf (2009) berpendapat bahwa motivasi belajar dipengaruhi oleh; (1) Faktor internal; terdiri dari faktor fisik (nutrisi atau gizi, kesehatan, dan berkaitan dengan fisik atau panca indera) dan faktor psikologis yang berkaitan dengan unsur-unsur yang memotivasi atau menghambat kegiatan belajar peserta didik, (2) Faktor eksternal; faktor yang muncul dari lingkungan seperti non-sosial (keadaan udara misal cuaca panas/dingin, waktu pagi/siang/malam, tempat sepi/bising, kualitas sekolah tempat belajar, serta sarana dan prasarana belajar) dan sosial (berkaitan dengan individu lain seperti guru, konselor, dan orang tua).

\section{Fasilitas Belajar}

Muhroji (2004) memaparkan bahwa fasilitas belajar yaitu sesuatu yang dibutuhkan pada kegiatan belajar mengajar yang bersifat bergerak dan tidak bergerak sehingga berjalan dengan lancar, teratur, efektif, dan efisien dalam rangka mewujudkan tujuan pendidikan. Sedangkan menurut Mulyasa (2004) menjelaskan bahwa fasilitas pembelajaran yaitu peralatan dan perlengkapan yang secara langsung dimanfaatkan untuk mendukung pendidikan, terutama dalam kegiatan belajar mengajar. Berdasarkan beberapa definisi tersebut, fasilitas belajar dapat disimpulkan sebagai peralatan dan perlengkapan baik bergerak dan tidak bergerak yang digunakan secara langsung dalam kegiatan pembelajaran dalam rangka mewujudkan tercapainya tujuan pendidikan yang berjalan efektif dan efisien. Menurut Sanjaya (2009), jenisjenis fasilitas belajar terbagi menjadi dua yaitu; (1) Sarana, adalah segala hal yang berhubungan langsung dengan peserta didik seperti alat-alat pelajaran, perlengkapan sekolah, media pembelajaran, dan sebagainya untuk menunjang kelancaran dan kesuksesan kegiatan pembelajaran, (2) Prasarana, adalah alat-alat yang secara tidak langsung mendukung jalannya proses pendidikan atau pengajaran misalnya halaman, kebun, taman sekolah, akses menuju sekolah.

\section{Kompetensi Guru}

Mulyasa (2007) bahwa kompetensi guru merupakan kombinasi kecakapan personalia, keilmuan, teknologi, sosial, dan spiritual yang membentuk kompetensi standar profesional guru, melingkupi penguasaan materi, memahami peserta didik, pembelajaran yang mendidik, 
pengembangan individu dan profesionalitas. Jamil (2014) berpendapat bahwa kompetensi guru yaitu penggabungan dari kecakapan-kecapakan dengan berbagai jenis bentuk seperti pengetahuan, keterampilan, dan perilaku yang harus dimiliki, dihayati, dan dikuasai seorang guru atau dosen pada saat menjalankan pekerjaannya. Berdasarkan beberapa penjelasan tersebut, kompetensi guru dapat didefinisikan sebagai keahlian yang dikuasai seorang guru berupa pemahaman, keterampilan, serta perilaku agar dapat diterapkan dalam proses pembelajaran. Berdasarkan Undang-Undang No 14. 14/2005 Pasal 10 ayat 1 dan PP No. $19 / 2005$ pasal 28 ayat 3, guru perlu mempunyai kompetensi pedagogik, kepribadian, sosial, dan professional yang didapatkan dengan menempuh pendidikan professional.

\section{Media Pembelajaran}

Angkowo dan Kosasih (2007) berpendapat bahwa media belajar adalah sesuatu yang dipakai dalam rangka menyampaikan informasi dan bermanfaat untuk menstimulus pemikiran, meningkatkan gairah belajar, ketertarikan, dan minat peserta didik terhadap pembelajaran sehingga memotivasi kegiatan belajar pada pribadi peserta didik. Pendapat lain dari Satrianawati (2017) menyampaikan mengenai media pembelajaran adalah peralatan dan perlengkapan yang digunakan dalam rangka mengefektifkan dan mengefisienkan proses pembelajaran supaya menggapai target pembelajaran yang telah ditentukan. Kesimpulan dari berbagai pemaparan pengertian media pembelajaran diatas adalah semua bahan yang dipakai untuk mendistribukan berita atau keterangan dari seorang guru kepada peserta didik untuk menciptakan kegiatan belajar mengajar menjadi lebih efektif dan efisien. Arsyad (2006) berpendapat jika media belajar mempunyai beberapa fungsi yaitu fungsi atensi, fungsi afektif, fungsi kognitif, fungsi kompensatoris, fungsi psikomotoris, dan fungsi evaluasi.

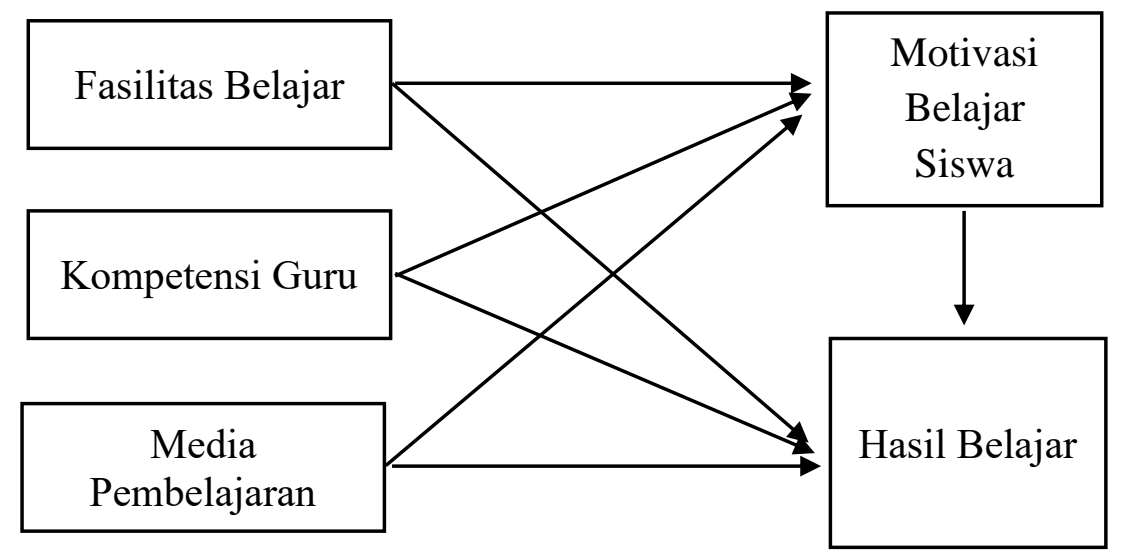

Gambar 1. Bagan pengembangan model penelitian empirik

\section{Perumusan Hipotesis}

Hipotesis dalam penelitian ini berdasarkan rumusan masalah, tinjauan pustaka dan penelitian terdahulu adalah:

$\mathrm{H}^{1}$ : Fasilitas belajar berpengaruh positif terhadap motivasi belajar siswa.

$\mathrm{H}^{2}$ : Kompetensi guru berpengaruh positif terhadap motivasi belajar siswa

$\mathrm{H}^{3}$ : Media pembelajaran mempunyai pengaruh positif terhadap motivasi belajar siswa

$\mathrm{H}^{4}$ : Fasilitas belajar berpengaruh positif terhadap hasil belajar siswa

$\mathrm{H}^{5}$ : Kompetensi guru berpengaruh positif terhadap hasil belajar siswa

$\mathrm{H}^{6}$ : Media pembelajaran terdapat pengaruh positif terhadap hasil belajar siswa

$\mathrm{H}^{7}$ : Motivasi belajar siswa berpengaruh positif terhadap hasil belajar siswa 
H8: Motivasi belajar memediasi pengaruh fasilitas belajar terhadap hasil belajar siswa $\mathrm{H}^{9}$ : Motivasi belajar memediasi pengaruh kompetensi guru terhadap hasil belajar $\mathrm{H}^{10}$ : Motivasi belajar memediasi pengaruh media pembelajaran terhadap hasil belajar

\section{METODE PENELITIAN}

Penelitian ini menggunakan pendekatan penelitian kuantitatif untuk menguji pengaruh kompetensi guru, fasilitas belajar, dan media pembelajaran sebagai variabel independen terhadap hasil belajar sebagai variabel dependen dengan motivasi belajar sebagai variabel mediasi. Populasi penelitian ini yaitu peserta didik Kompetensi Keahlian Bisnis Daring dan Pemasaran di SMK Se-Kecamatan Bumiayu. Berdasarkan perhitungan rumus Slovin, total sampel yang ada pada penelitian ini sebanyak 120 peserta didik. Teknik pengambilan sampel yang digunakan peneliti adalah proportionate random sampling atau disebut juga dengan pengambilan sampel secara acak dan proporsional. Tujuan dari teknik pengambilan sampel ini adalah supaya peneliti memperoleh sampel representatif dari seluruh populasi (Riduwan dan Sunarto, 2017). Metode pengambilan data dilakukan dengan metode survei. Alat pengumpulan data yang digunakan adalah kuesioner.

\section{TEKNIK ANALISIS DATA}

Teknik analisis yang digunakan dalam penelitian ini adalah analisis jalur (path analysis). Dalam penelitian ini penyelesaian masalah analisis jalur dapat diselesaikan melalui pendekatan regresi linear. Analisis regresi berganda bertujuan untuk menduga besarnya koefisien regresi yang akan menunjukan besarnya pengaruh variabel kompetensi guru, fasilitas belajar, media pembelajaran dan motivasi siswa terhadap variabel hasil belajar. Persamaan umum yang digunakan adalah:

$$
Y=\alpha+\rho_{1} X_{1}+\rho_{2} X_{2}+\rho_{3} X_{3}+\rho_{4} M_{4}+e
$$

\section{Keterangan:}

$\alpha \quad=$ konstanta

$\rho_{1} \quad=$ koefisien regresi fasilitas belajar

$\rho_{2} \quad=$ koefisien regresi kompetensi guru

$\rho_{3} \quad=$ koefisien regresi media pembelajaran

$\rho_{3} \quad=$ koefisien regresi motivasi belajar

$\mathrm{X}_{1} \quad=$ fasilitas belajar

$\mathrm{X}_{2} \quad=$ kompetensi guru

$\mathrm{X}_{3} \quad=$ media pembelajaran

$\mathrm{M}_{4} \quad=$ motivasi belajar

$\mathrm{Y} \quad=$ Hasil belajar

e $\quad=\operatorname{error}\left(\right.$ tingkat kesalahan atau $e=\sqrt{1-R^{2}}$ )

\section{HASIL DAN PEMBAHASAN \\ Uji Validitas}

Nilai pearson correlated (r-hitung) semua item pernyataan dari variabel fasilitas belajar, kompetensi guru, media pembelajaran, motivasi belajar dan hasil belajar lebih besar dari r-tabel sehingga dapat disimpulkan bahwa semua item pernyataan pada variabel fasilitas belajar valid.

\section{Uji Reliabilitas}

Suatu variabel dikatakan reliabel jika memberikan nilai Cronbach Alpha $>0,6$. Nilai Cronbach's Alpha dari variabel fasilitas belajar, kompetensi guru, media pembelajaran, motivasi 
belajar dan hasil belajar lebih besar dari nilai minimum 0,6 sehingga dapat disimpulkan bahwa semua variabel dinyatakan reliabel.

\section{Uji Asumsi Klasik (Multikolinearitas, Normalitas, dan Heterokedastisitas) Uji Multikolinearitas}

Uji multikolinieritas bertujuan untuk menguji apakah model regresi ditemukan adanya korelasi antar variabel bebas (independen). Hasil dari perhitungan nilai Tolerance dan Variabel Inflation Factor (VIF) baik pada persamaan I dan persamaan II menunjukkan bahwa tidak ada variabel bebas yang memiliki nilai Tolerance kurang dari 0,10 (tolerance $>0,10$ ) dan nilai VIF semuanya kurang dari 10 . Selain itu nilai standar error kurang dari satu (std. error $<1$ ) sehingga tidak terdapat multikolinieritas antar variabel bebas dalam model regresi atau variabel dapat dipercaya dan obyektif.

\section{Uji Normalitas}

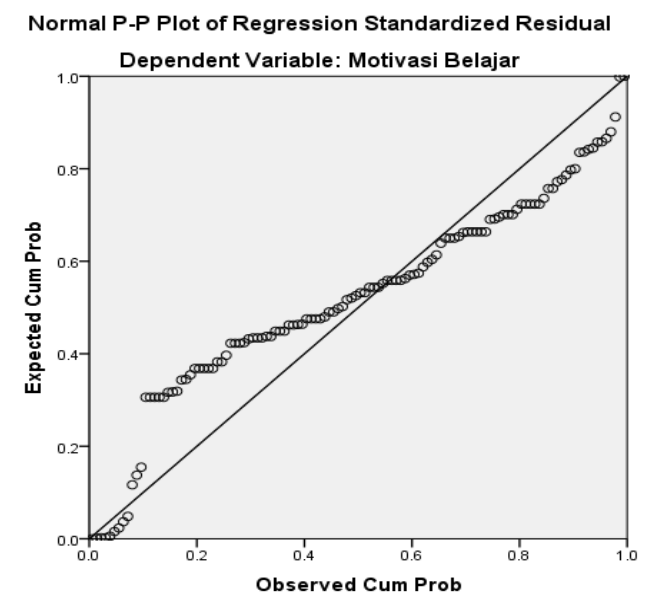

Gambar 2 Uji Normalitas Persamaan I

Sumber: Data Primer Diolah, 2019

Berdasarkan gambar 2 uji normalitas terlihat bahwa data menyebar di sekitar garis diagonal dan mengikuti arah garis diagonal. Maka model regresi memenuhi asumsi normalitas.

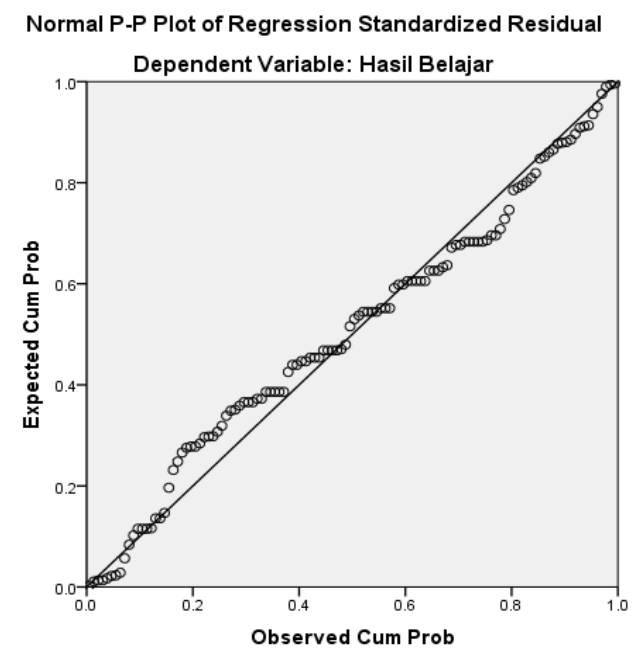

Gambar 3 Uji Normalitas Persamaan II

Sumber: Data Primer Diolah, 2019 
Berdasarkan gambar 3 uji normalitas terlihat bahwa data menyebar di sekitar garis diagonal dan mengikuti arah garis diagonal. Maka model regresi memenuhi asumsi normalitas.

\section{Uji Heterokedastisitas}

Hasil analisis diperoleh sebagai berikut:

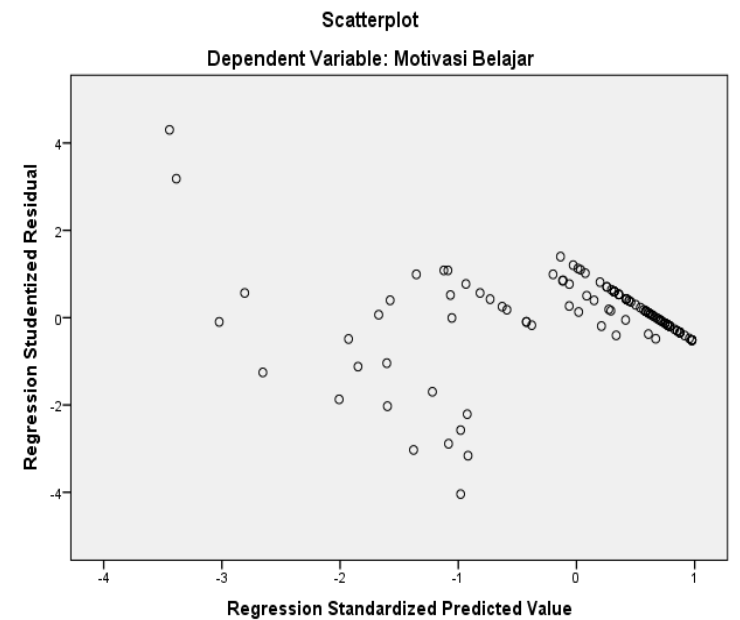

Gambar 4 Uji Heterokedastisitas Persamaan I

Sumber: Data Primer Diolah, 2019

Berdasarkan gambar 4 menunjukkan bahwa tidak ada pola tertentu, seperti gelombang, bentuk menyempit, menyebar, dan tidak ada pola lain yang jelas. Hal ini menunjukkan bahwa tidak terjadi heterokedastisitas di model regresi.

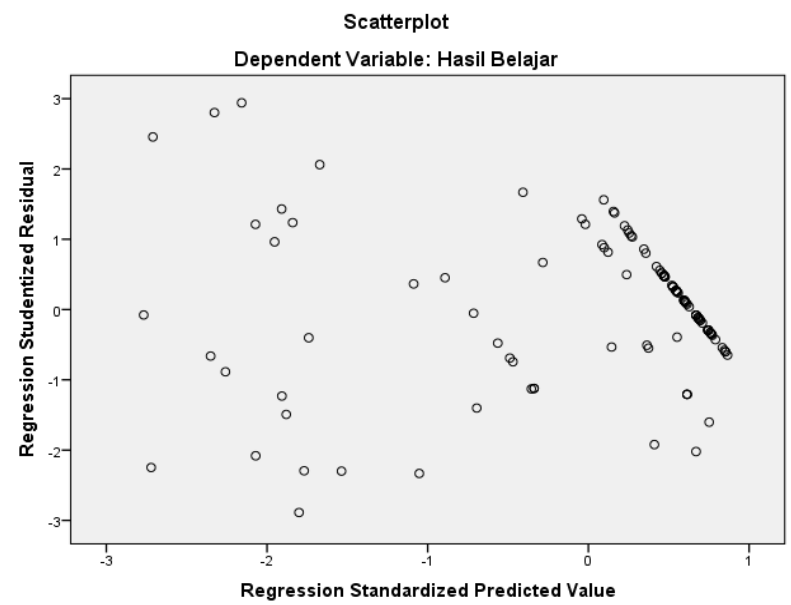

Gambar 5 Uji Heterokedastisitas Persamaan II

Sumber: Data Primer Diolah, 2019

Berdasarkan gambar 5 menunjukkan bahwa tidak ada pola tertentu, seperti titik-titik yang membentuk suatu pola tertentu yang teratur (bergelombang, melebar, kemudian menyempit) dan tidak ada pola yang jelas sehingga dapat disimpulkan mode regresi tidak terjadi heterokedastisitas.

\section{Pengujian Hipotesis}

\section{Uji F}

Uji F pada dasarnya memperlihatkan apakah semua variabel independen yang dimasukkan dalam model mempunyai pengaruh secara bersama-sama atau simultan terhadap 
variabel dependen. Nilai signifikansi pada uji $\mathrm{F}$ jika lebih kecil dari 0,05 dapat disimpulkan bahwa variabel bebas secara simultan mampu menjelaskan perubahan variabel tergantung atau model dinyatakan cocok atau fit. Pada Persamaan Regresi I, nilai pengaruh langsung dan tidak langsung antara variabel bebas fasilitas belajar, kompetensi guru dan media pembelajaran terhadap variabel bebas motivasi belajar. Nilai pengaruh masing-masing variabel yaitu fasilitas belajar 0,000, motivasi belajar 0,018 dan media pembelajaran 0,0000, karena nilai-nilai tersebut lebih kecil dari 0,05 maka variabel fasilitas belajar, kompetensi guru dan media pembelajaran berpengaruh langsung terhadap motivasi.

Pada Persamaan Regresi II, menyajikan nilai pengaruh masing-masing variabel bebas yaitu fasilitas belajar, kompetensi guru, media pembelajaran, dan motivasi belajar terhadap variabel terikat yaitu hasil belajar. Nilai pengaruh fasilitas belajar, media pembelajaran dan motivasi belajar adalah .000, karena $0,000<0,05$ maka variabel-variabel tersebut berpengaruh secara langsung terhadap variabel hasil belajar. Berbeda dengan variabel kompetensi guru yang bernilai .685, karena 0,685 >0,05 maka variabel kompetensi guru berpengaruh secara tidak langsung terhadap variabel hasil belajar.

\section{Uji Koefisien Determinasi Simultan $\left(\mathbf{R}^{2}\right)$}

Koefisien determinasi $\left(\mathrm{R}^{2}\right)$ berguna untuk memprediksi dan melihat seberapa besar kontribusi pengaruh yang diberikan variabel bebas secara bersama-sama terhadap variabel terikat. Pada Persamaan Regresi I, kontribusi yang diberikan variabel bebas yaitu kompetensi guru, media pembelajaran, dan fasilitas belajar terhadap variabel terikat motivasi belajar adalah sebanyak .735 atau 73,5\%, sedangkan 26,5\% lainnya berasal dari faktor lain yang tidak diteliti. Pada Persamaan Regresi II, kontribusi yang diberikan variabel bebas yaitu kompetensi guru, media pembelajaran, fasilitas belajar, dan motivasi terhadap variabel terikat motivasi belajar adalah sebanyak .885 atau 88,5\%, sedangkan 11,5\% lainnya berasal dari faktor lain yang tidak diteliti.

\section{Uji t}

Nilai t hitung digunakan untuk menguji apakah variabel tersebut berpengaruh secara signifikan terhadap variabel dependen atau tidak (Suliyanto, 2011). Hasil uji t ditunjukkan pada tabel 2 dibawah ini:

Tabel 2 Hasil Uji Parsial (Uji t)

\begin{tabular}{|c|c|c|c|}
\hline \multirow{2}{*}{ No. } & \multirow{2}{*}{ Variabel } & \multicolumn{2}{|c|}{ Pengaruh } \\
\hline & & Hasil Belajar & Motivasi Belajar \\
\hline 1 & Fasilitas Belajar & $\begin{array}{l}4,755 \\
\text { Sig. } 0,000\end{array}$ & $\begin{array}{l}14,524 \\
\text { Sig. } 0,000\end{array}$ \\
\hline 2 & Kompetensi Guru & $\begin{array}{l}-0,406 \\
\text { Sig. } 0,685\end{array}$ & $\begin{array}{l}2,409 \\
\text { Sig. 0,018 }\end{array}$ \\
\hline 3 & Media Pembelajaran & $\begin{array}{l}5,398 \\
\text { Sig. 0,000 }\end{array}$ & $\begin{array}{l}4,830 \\
\text { Sig. 0,000 }\end{array}$ \\
\hline 4 & Motivasi Belajar & $\begin{array}{l}10,066 \\
\text { Sig. } 0,000\end{array}$ & \\
\hline
\end{tabular}

Sumber: Data Primer Diolah, 2019

Berdasarkan tabel 2, diperoleh t hitung sebesar 14,524 > t tabel 1,65821 dengan tingkat signifikansi $0,000<0,05$ berarti variabel fasilitas belajar berpengaruh positif dan signifikan terhadap motivasi belajar. Hal ini menunjukan bahwa $\mathrm{H} 1$ "fasilitas belajar berpengaruh positif motivasi belajar" diterima. 
Berdasarkan tabel 2, diperoleh $\mathrm{t}$ hitung sebesar 2,409 > t tabel 1,65821 dengan tingkat signifikansi $0,018<0,05$ berarti variabel kompetensi guru berpengaruh positif dan signifikan terhadap motivasi belajar. Hal ini menunjukan bahwa H2 "kompetensi guru berpengaruh positif terhadap motivasi belajar" diterima.

Berdasarkan tabel 2, diperoleh thitung sebesar 4,830 > t tabel 1,65821 dengan tingkat signifikansi $0,000<0,05$ berarti variabel media pembelajaran berpengaruh positif dan signifikan terhadap motivasi belajar. Hal ini menunjukan bahwa H3 "media pembelajaran berpengaruh positif terhadap motivasi belajar" diterima.

Berdasarkan tabel 2, diperoleh $\mathrm{t}$ hitung sebesar 4,755 $>\mathrm{t}$ tabel 1,65821 dengan tingkat signifikansi $0,000<0,05$ berarti variabel fasilitas belajar berpengaruh positif dan signifikan terhadap hasil belajar. Hal ini menunjukan bahwa H4 "fasilitas belajar berpengaruh positif terhadap hasil belajar" diterima.

Berdasarkan tabel 2, diperoleh $t$ hitung sebesar $-0,406<\mathrm{t}$ tabel 1,65821 dengan tingkat signifikansi $0,685<0,05$ berarti variabel kompetensi guru tidak berpengaruh terhadap hasil belajar. Hal ini menunjukan bahwa H5 "kompetensi guru berpengaruh positif terhadap hasil belajar" ditolak.

Berdasarkan tabel 2, diperoleh $\mathrm{t}$ hitung sebesar 5,398 $>\mathrm{t}$ tabel 1,65821 dengan tingkat signifikansi $0,000<0,05$ berarti variabel media pembelajaran berpengaruh positif dan signifikan terhadap hasil belajar. Hal ini menunjukan bahwa H6 "media pembelajaran berpengaruh positif terhadap hasil belajar" diterima.

Berdasarkan tabel 2, diperoleh t hitung sebesar 10,066 > t tabel 1,65821 dengan tingkat signifikansi $0,000<0,05$ berarti variabel motivasi belajar berpengaruh positif dan signifikan terhadap hasil belajar. Hal ini menunjukan bahwa H7 "motivasi belajar berpengaruh positif terhadap hasil belajar" diterima.

\section{Uji Jalur (Path Analysis)}

Analisis jalur dilakukan untuk mengetahui pengaruh dari variabel intervening yang digunakan dalam penelitian ini yaitu motivasi siswa (Sugiono, 2014). Hasil analisis jalur (path analysis) ditunjukkan dalam gambar 6 berikut ini:

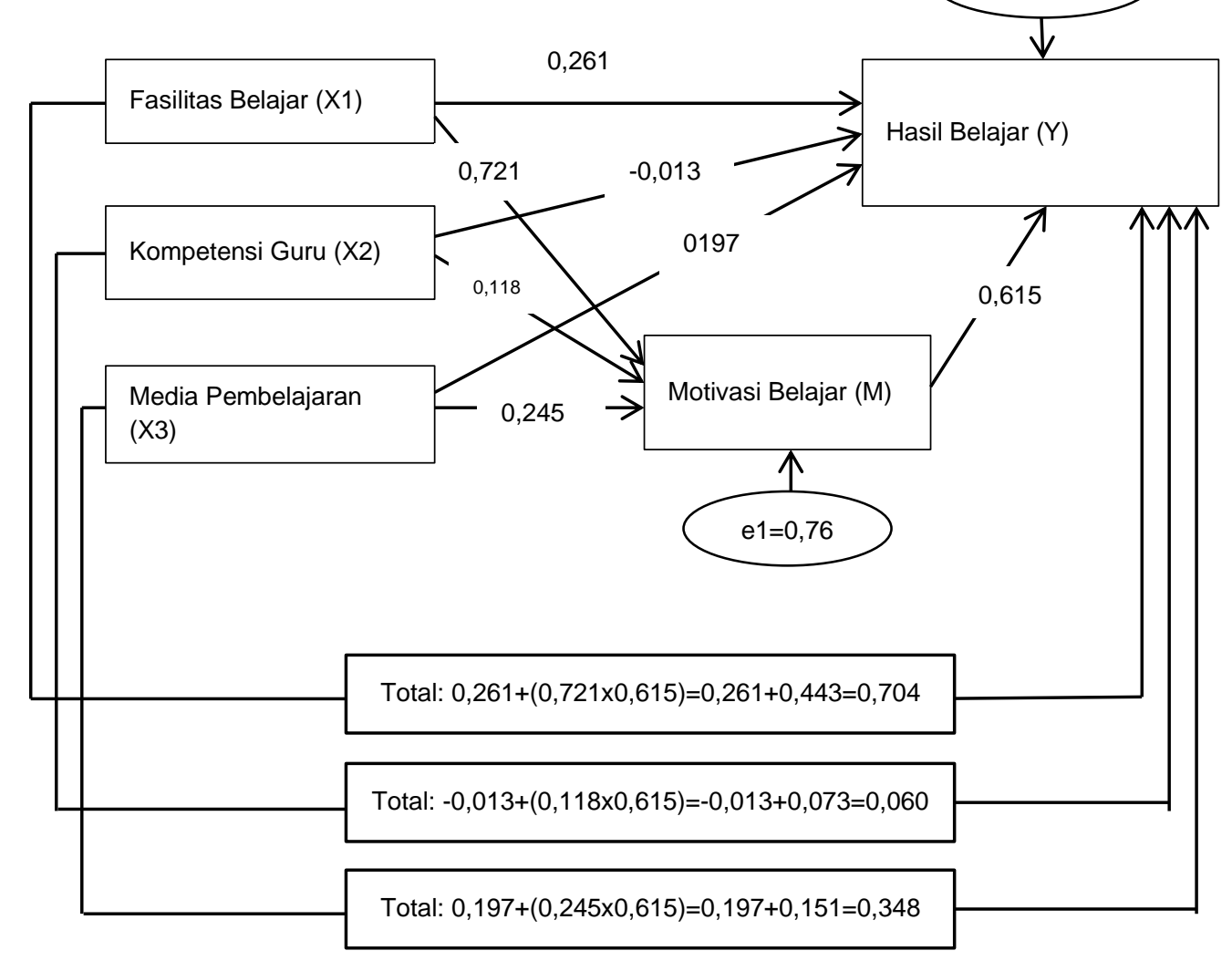




\section{Uji Sobel}

\section{Gambar 6 Hasil Analisis Jalur (Path Analysis)}

Berdasarkan perhitungan Sobel Test Calculator, diperoleh thitung 8,273 lebih besar dari $t_{\text {tabel }}$ 1,96 dengan tingkat signifikansi 0,05 maka dapat disimpulkan bahwa koefisien mediasi motivasi belajar signifikan dan berpengaruh dalam memediasi hubungan fasilitas belajar terhadap hasil belajar. Hal ini menunjukan bahwa H8 "motivasi belajar memediasi pengaruh fasilitas belajar terhadap hasil belajar siswa" diterima.

Berdasarkan perhitungan Sobel Test Calculator, diperoleh thitung 2,343 lebih besar dari $t_{\text {tabel }}$ 1,96 dengan tingkat signifikansi 0,05 maka dapat disimpulkan bahwa koefisien mediasi motivasi belajar signifikan dan berpengaruh dalam memediasi hubungan kompetensi guru terhadap hasil belajar. Hal ini menunjukan bahwa H9 "motivasi belajar memediasi pengaruh kompetensi guru terhadap hasil belajar" diterima.

Berdasarkan perhitungan Sobel Test Calculator, diperoleh $t_{\text {hitung }}$ 4,355 lebih besar dari $t_{\text {tabel }} 1,96$ dengan tingkat signifikansi 0,05 maka dapat disimpulkan bahwa koefisien mediasi motivasi belajar signifikan dan berpengaruh dalam memediasi hubungan media pembelajaran terhadap hasil belajar. Hal ini menunjukan bahwa H9 "motivasi belajar memediasi pengaruh media pembelajaran terhadap hasil belajar" diterima.

\section{KESIMPULAN}

Hasil penelitian menunjukan bahwa fasilitas belajar, kompetensi guru dan media pembelajaran berpengaruh terhadap motivasi belajar. Hal ini menunjukkan bahwa semakin memadai ketiga faktor eksternal tersebut, maka motivasi belajar siswa akan semakin tinggi dan sebaliknya jika ketiga faktor eksternal tersebut tidak memadai, maka motivasi belajar siswa rendah. Selain itu, Fasilitas belajar dan media pembelajaran berpengaruh positif terhadap hasil belajar. Hal ini menunjukkan bahwa semakin baik fasilitas belajar dan media pembelajaran maka hasil belajar siswa akan semakin tinggi dan sebaliknya jika fasilitas belajar dan media pembelajaran tidak baik, maka hasil belajar siswa rendah. Namun, kompetensi guru tidak berpengaruh positif terhadap hasil belajar. Hal ini menunjukkan bahwa semakin tinggi kompetensi guru tidak menyebabkan hasil belajar siswa semakin tinggi.

Dilain pihak, motivasi belajar berpengaruh positif terhadap hasil belajar. Hal ini menunjukkan bahwa semakin tinggi motivasi belajar maka semakin tinggi hasil belajar siswa dan sebaliknya jika motivasi belajar rendah maka hasil belajar siswa rendah. Selain itu, fasilitas belajar, kompetensi guru dan media pembelajaran berpengaruh positif terhadap hasil belajar melalui motivasi belajar. Dalam hal ini motivasi belajar berperan sebagai partial mediation. Artinya, fasilitas belajar dan media pembelajaran mampu memengaruhi secara langsung terhadap hasil belajar namun semua faktor eksternal tersebut mampu mempengaruhi secara tidak langsung melalui motivasi belajar sebagai variabel mediasi.

\section{IMPLIKASI}

Motivasi belajar dapat ditingkatkan dengan cara menyediakan fasilitas belajar yang memadai, peningkatan kompetensi guru yang baik dan menggunakan media pembelajaran yang efektif. Hasil belajar dapat ditingkatkan dengan fasilitas belajar yang memadai, penggunaan media pembelajaran yang efektif, dan motivasi belajar peserta didik. Sekolah dan orangtua perlu menciptakan kondisi lingkungan yang mendukung proses pembelajaran. Hal ini dapat dilakukan 
dengan menyediakan fasilitas belajar yang memadai seperti ruangan kelas kondusif, nyamannya ruangan perpustakaan untuk belajar dengan ketersediaan buku yang lengkap, lapangan untuk olahraga, laboratorium beserta peralatan praktik kejuruan maupun mata pelajaran lainnya supaya peserta didik lebih semangat dalam melaksanakan kegiatan belajar.

Dalam kegiatan belajar mengajar, guru juga dapat menyampaikan materi menggunakan media pembelajaran yang menarik supaya membuat suasana pembelajaran tidak terasa membosankan. Suasana pembelajaran yang tidak membosankan dapat membuat peserta didik lebih semangat dalam belajar. Walaupun kompetensi guru tidak memberikan pengaruh terhadap hasil belajar, namun sudah sepatutnya bagi seorang guru untuk terus meningkatkan kompetensi dalam memotivasi belajar peserta didik sehingga mereka mampu meningkatkan hasil belajar. Dengan mengikuti pelatihan dan kegiatan lain yang dapat memperkaya potensi profesinya agar mampu mengembangkan proses pembelajaran menjadi lebih menarik sehingga lebih meningkatkan semangat belajar siswa.

Peningkatan hasil belajar peserta didik dapat didukung dengan tersedianya fasilitas belajar yang memadai, kompetensi guru yang baik, dan penggunaan media pembelajaran dalam kegiatan belajar mengajar dan pengaruhnya akan lebih baik jika didukung oleh motivasi belajar. Sekolah dapat melengkapi fasilitas yang tersedia sebagai bentuk dukungan dalam proses kegiatan belajar mengajar sehingga peserta didik dan guru mampu menjalankan kegiatan secara optimal. Penggunaan media pembelajaran dan fasilitas yang memadai dapat membuat peserta didik akan lebih semangat lagi dalam belajarnya sehingga mampu meningkatkan hasil belajar.

\section{KETERBATASAN PENELITIAN}

Keterbatasan jumlah sekolah yang terdapat Kompetensi Keahlian Bisnis Daring dan Pemasaran hanyalah 2 sekolah di wilayah Bumiayu dengan jumlah responden hanya 120 orang, tentunya masih kurang untuk menggambarkan keadaan yang sesungguhnya. Penelitian ini menggunakan data kuesioner yang disebarkan kepada peserta didik. Terdapat kemungkinan kelemahan menggunakan kuisoner yaitu semua responden yang mengisi kuesioner tidak sesuai dengan yang kita maksud karena peserta didik memiliki perbedaan persepsi dan pemahaman yang kurang tepat terhadap kuesioner. Penelitian berikutnya bisa melakukannya dengan wawancara maupun teknik lain yang mampu memberikan informasi nyata tentang hasil belajar.

\section{DAFTAR PUSTAKA}

Amah, Nik. (2015). Pengaruh Fasilitas Sekolah Terhadap Hasil Belajar Akuntansi dengan Lingkungan Sosial sebagai Pemoderasi. Journal of Accounting and Business Education.

Angkowo, Robertus dan A. Kosasih. (2007). Optimalisasi Media Pembelajaran. Jakarta: PT Grasindo.

Arikunto, Suharsimi. (2003). Dasar-Dasar Evaluasi Pendidikan. Jakarta: Bumi Aksara.

Arsyad, Azhar. (2006). Media Pembelajaran. Depok: PT Rajagrafindo Persada.

Aunurrahman. (2014). Belajar dan Pembelajaran. Bandung: Alfabeta.

Bafadal, Ibrahim. (2004). Manajemen Perlengkapan Sekolah Dan Aplikasinya. Jakarta: Bumi Aksara.

Barnawi dan Mohammad Arifin. (2014). Instrumens Pembinaan, Peningkatan dan Penilaian Kinerja Guru Profesional. Yogyakarta: Ar-Ruzz Media.

Darojah, Nur Rofiah. (2016). Analisis Pengaruh Kompetensi Kepribadian Guru dengan Motivasi Belajar Sebagai Variabel Intervening Terhadap Prestasi Belajar Siswa Kelas X Administrasi Perkantoran. Jurnal Pendidikan Manajemen Perkantoran, 1, 109-118.

Dewi, Embuni. (2016). Pengaruh Fasilitas Belajar terhadap Hasil Belajar Siswa Kelas X Program Keahlian Akuntansi di SMK Kansai Pekanbaru. Jurnal Online Mahasiswa Fakultas Keguruan dan Ilmu Pendidikan Universitas Riau (JOM FKIP UNRI). 
Djamarah, Syaiful Bahri, dkk. (2002). Strategi Belajar Mengajar. Jakarta: Rineka Cipta

Dimyati dan Mudjiono. (2010). Belajar dan Pembelajaran. Jakarta: PT Rineka Cipta.

Ellyana, Veronika. (2016). Pengaruh Kompetensi Guru Terhadap Motivasi Belajar Siswa Pada Mata Pelajaran Kewirausahaan di SMK Kristen 1 Surakarta. BISE: Jurnal Pendidikan Bisnis dan Ekonomi, 2.

Ghozali, Imam. (2009). “Aplikasi Analisis Multivariate dengan Program SPSS”. Semarang: UNDIP.

Gie, The Liang. (2002). Administrasi Perkantoran Modern. Liberty. Yogyakarta.

Hartono. (2010). Statistik untuk penelitiaan. Yogyakarta: Pustaka Pelajar.

Jamil, Suprihatiningrum. (2014). Strategi Pembelajaran.Yogyakarta: Ar-Ruzz Media.

Janawi. (2011). Kompetensi Guru: Citra Guru Profesional. Bandung: Alfabeta.

Koriaty, Sri. (2017). Pengaruh Kompetensi Guru Terhadap Motivasi Belajar Siswa SMK Negeri Jurusan TKJ Sekota Pontianak. Jurnal Pendidikan Informatika dan Sains, 6.

Kunandar. (2010). Guru Profesional. Jakarta: Rajawali Press.

Kurniawan, Rizal. (2012). Pengaruh Lingkungan Sekolah, Motivasi Belajar Dan Fasilitas Belajar Terhadap Hasil Belajar Siswa Pada Mata Pelajaran Peralatan Kantor Kelas X Administrasi Perkantoran SMK Negeri 1 Kudus Tahun Pelajaran 2012/2013. Economic Education Analysis Journal, 3.

Minarti, Sri. (2011). Manajemen Sekolah: Mengelola Lembaga Pendidikan Secara Mandiri. Jogjakarta: ArRuzz Media.

Muhroji. (2004). Manajemen Pendidikan. Surakarta: FKIP UMS.

Mulyasa, E. (2004). Kurikulum Berbasis Kompetensi. Bandung: Remaja Rosdakarya.

Musfah, Jejen. (2015). Peningkatan Kompetensi Guru Melalui Pelatihan dan Sumber Belajar Teori dan Praktik. Jakarta: Prenadamedia Group.

Novalinda, Eri. (2017). Pengaruh Motivasi Belajar Terhadap Hasil Belajar Mata Pelajaran Akuntansi Siswa Kelas X Jurusan Akuntansi Semester Ganjil SMK PGRI 5 Jember Tahun Pelajaran 2016/2017. Jurnal Pendidikan Ekonomi: Jurnal Ilmiah Ilmu Pendidikan, Ilmu Ekonomi, dan Ilmu Sosial, 11.

Novauli, Feralys. (2012). Pengaruh Kompetensi Guru Terhadap Peningkatan Prestasi Belajar Pada SMP Negeri di Kota Banda Aceh. Jurnal Pencerahan, 6, 17-32.

Nurmala, Desy Ayu. (2014). Pengaruh Motivasi Belajar dan Aktivitas Belajar Terhadap Hasil Belajar Akuntansi. Jurnal Pendidikan Ekonomi Undiksha, 4.

Prasetyo, Arif Nur. (2015). Pengaruh Kompetensi Pedagogik Guru dan Disiplin Belajar Melalui Motivasi Belajar Sebagai Variabel Intervening Terhadap Prestasi Belajar. Economic Education Analysis Journal, 4 .

Putri, Wakhidati Nurrohmah. (2017). Pengaruh Media Pembelajaran Terhadap Motivasi Belajar Bahasa Arab Siswa Madrasah Tsanawiyah. Journal of Arabic Education and Literature, 1, 1-16.

Riduwan dan Sunarto. (2017). Pengantar Statistika Untuk Penelitian Pendidikan, Sosial, Komunikasi, Ekonomi. Bandung: Alfabeta.

Rifa'i, Achmad., dan Catharina Tri Anni. (2012). Psikologis Pendidikan. Semarang: Universitas Negeri Semarang Press.

Rofa'ah. (2016). Pentingnya Kompetensi Guru dalam Kegiatan Pembelajaran dalam Perspektif Islam. Yogyakarta: Deepublish.

Sadiman, Arief., Dkk. (2009). Media Pendidikan: Pengertian, Pengembangan dan Pemanfaatannya. Jakarta: Raja Grafindo Persada.

Sanjaya, Wina. (2005). Pembelajaran dalam Implementasi Kurikulum Berbasis Kompetensi. Jakarta: Kencana Prenada Media Group.

Sanjaya, Wina. (2009). Strategi Pembelajaran Berorientasi Standar Proses Pendidikan. Jakarta: Kencana.

Sardiman, A.M. (2014). Interaksi dan Motivasi Belajar Mengajar. Jakarta: Rajawali Pers. 
Satrianawati. (2017). Media dan Sumber Belajar. Yogyakarta: Deepublish.

Sholekhah, Ika Maratus. (2014). Pengaruh Fasilitas Belajar dan Lingkungan Keluarga Terhadap Hasil Belajar IPS Terpadu Melalui Motivasi Belajar SMP Negeri 1 Ambarawa. Economic Education Analysis Journal, 3.

Slameto. (2003). Belajar dan Faktor-Faktor yang Mempengaruhinya. Jakarta: Rineka Cipta.

Sudjana, Nana. (2009). Penilaian Hasil Proses Belajar Mengajar. Bandung: PT. Remaja Rosdakarya.

Sudjana, Nana dan Ahmad Rivai. (2002). Media Pembelajaran. Bandung: Sinar Baru Algensindo.

Sudjana, Nana. (2012). Penelitian Hasil Proses Belajar Mengajar. Bandung: Remaja Rosda Karya.

Sugiyono. (2016). Metode Penelitian Pendidikan (Pendekatan Kuantitatif, Kualitatif dan R\&D). Penerbit CV. Alfabeta: Bandung.

Suliyanto. (2011). Ekonometrika Terapan- Teori dan Aplikasi dengan SPSS. Yogyakarta: CV.Andi Offset.

Supardi. (2016). Aplikasi Statistika dalam Penelitian Konsep Statistika yang Lebih Komprehensif. Jakarta: Change Publication.

Surya, Mohammad. (2004). Psikologi Pembelajaran dan Pengajaran. Bandung: Pustaka Bani Quraisy.

Suryosubroto, B. (2004). Manajemen Pendidikan di Sekolah. Jakarta: Rineka Putra.

Susanto, Ahmad. (2013). Teori Belajar dan Pembelajaran di Sekolah Dasar. Jakarta: Kencana Prenada Media Group.

Sutardi (2016). Pengaruh Kompetensi Guru, Motivasi Belajar, dan Lingkungan Keluarga Terhadap Hasil Belajar Mata Pelajaran Ekonomi. Harmoni Sosial: Jurnal Pendidikan IPS, 3, 188-198.

Tirtiana, Chandra Putri. (2013). Pengaruh Kreativitas Belajar, Penggunaan Media Pembelajaran Power Point, dan Lingkungan Keluarga Terhadap Hasil Belajar Mata Pelajaran Akuntansi Pada Siswa Kelas X Akuntansi SMK Negeri 2 Blora Tahun Ajaran 2012/2013 (Motivasi Belajar Sebagai Variabel Intervening). Economic Education Analysis Journal, 2.

Uno, Hamzah B. (2007). Profesi Kependidikan: Problema, Solusi dan Reformasi Pendidikan di Indonesia. Jakarta: Bumi Aksara.

Uno, Hamzah B. (2011). Teori Motivasi dan Pengukurannya. Jakarta: PT. Bumi Aksara

Usman, Moh. Uzer. (2011). Menjadi Guru Professional. Bandung: PT Remaja Rosdakarya.

Wahyuningrum, Kartika. (2015). Pengaruh Fasilitas Belajar di Sekolah terhadap Motivasi Belajar Siswa Kelas V SD Dabin IV Kecamatan Pituruh Kabupaten Purworejo.

Winkel, WS. (2000). Psikologi Pendidikan dan Evaluasi Belajar. Jakarta: Gramedia.

Yuliani, Prastiwi. (2014). Pengaruh Fasilitas Belajar, Pengelolaan Kelas, dan Lingkungan Keluarga Terhadap Hasil Belajar Ekonomi Melalui Motivasi Belajar Siswa Kelas XI Ma Al-Asror Kota Semarang. Economic Education Analysis Journal, 3.

Yusuf, Syamsu. (2009). Program Bimbingan dan Konseling di Sekolah. Bandung: Rizqi Press. 